\title{
AMP (感情誤帰属手続き) による潜在過程の検討 (1)
}

\author{
- 潜在測度と顕在測度による自己制御行動の予測 - \\ ○及川昌典 ${ }^{1} \cdot$ 青林唯 $^{2} \cdot$ 木村晴 ${ }^{3}$ \\ $\left({ }^{1}\right.$ 一橋大学 $\cdot{ }^{2}$ 千葉大学 ${ }^{3}$ 学習院大学 $\cdot$ 日本学術振興会 $)$
}

\section{Key words: 感情誤帰属手続き 自己制御 潜在態度}

\section{目的}

本研究では, ペインら(Payne,Cheng,Govorun,\&Stewart, 2005) によって開発された，新たな潜在指標である感情誤帰属手続き (Affect Misattribution Procedure) を用いて, 潜在態度が日常の 行動に及ぼす影響を検討した。

AMP とは, 曖昧事象を解釈するときに, 自らの内的状態を“誤” 帰属することを利用した，潜在態度の測定である. 具体的には, 対 象刺激の呈示後, 曖昧な中性刺激を呈示し，それを「好きか嫌いか」 の判断をさせると, その中性刺激への判断に, 最初に提示した刺激 への評価が混入することを利用したものである.ペインらの報告に よると, AMPは, 従来の潜在態度の指標と比べて, 高い信頼性と 測定感度を備えており (Payne, Cheng, Govorun, \& Stewart, 2005)，また，実施が簡便であるという利点を持っている.

本研究では, この新たな指標の妥当性を, 自己制御の枠組みから 検討寸る. 研究 1 では，「勉強（目標）」と「遊び (誘惑)」に対す る潜在態度を測定し，これが，一力月後の実際の自己制御行動（冬 休み中のテスト勉強量）を予測するかを検討する。 また, 顕在態度 （自己報告尺度）との比較を試みる. 調查 2 では, 状況が潜在態度 に影響を及ぼす可能性を検討寸る. 具体的には, 勉強へ動機づけが 高まっているテスト期間中に, 潜在態度を測定すると, 勉強に対す る潜在態度がポジティブに, 遊びに対する潜在態度がネガティブに 現れる可能性を検討する.

\section{研究 1}

\section{1. 目的}

AMP による「遊び「勉強」への潜在態度が，一力月後の実際 の行動をどの程度予測するかを検討する.

\section{2. 方法}

参加者 大学生 27 名 (男性 16 名, 女性 11 名).

手続き 冬休み前に, 感情誤帰属手続きによって遊びと勉強に対す る潜在態度を測定し, 質問紙によって顕在態度を測定した. 冬休み 明けに，休み中の行動について報告させた。

\section{（1）潜在態度測定：(2005 年 12 月初旬)}

勉強と遊びに対する AMP を行った。これは曖昧図形に対する印 象判断の課題であり, 参加者は, 先行刺激 (画像プライム), ター ゲット刺激 (曖昧図形) の順に刺激が呈示されるので, 先行刺激に 影響されずにターゲット刺激の印象を判断するようにと教示され た. 実際には，プライムは $75 \mathrm{~ms}$ 呈示されて消え， $125 \mathrm{~ms}$ のブラ ンクを置いて，ターゲットが $100 \mathrm{~ms}$ 呈示された. ターゲットが消 えた後は四角い灰色のマスクが呈示され，参加者はこの間に，ター ゲットに対する印象判断を「好き」か, 「嫌い」の強制2 択で報告 した. プライムには, 予備調查によって選出された勉強関連画像,
遊び関連画像，四角い灰色のマスク(各 12 枚)のいずれかがランダ ム順で呈示された. ターゲットには, 印象評価が暧昧な刺激 36 枚 (イ音節文字) が使用された. よって, 課題は全 36 回試行であり, 所要時間は約 3 分であった.

（2）顕在態度指標：(潜在指標測定から約 2週間後)

一般的な自己制御に関する項目に混ぜて，「私は勉強が好きだ」 や「私にとって勉強は重要だ」などの勉強と遊びに対する態度を尋 ねる項目に 7 件法で回答させた.

（3）行動報告：(2006 年 1 月実施)

冬休みをどのように過ごしたか, 回顧的な自己報告を求めた. 遊 びに関しては, TV, 友人と遊ぶ, 趣味に費やした時間の 3 項目. 勉強に関しては，勉強に費やした時間を評定させた。

\section{3. 結果と考察}

AMP の全体傾向 遊びプライムにおけるポジティブ反応率（60\%) は, 勉強プライム (49\%) や中性プライム (51\%) に比べて有意に高かっ た $(F(2,52)=3.25, p \nmid .05)$. 参加者は, 遊びをポジティブに捉えてい ることを示寸。

遊びAMP 遊び AMP の得点を中央值折半し, 潜在態度遊び高群と 低群に分けて, 冬休み中の遊び関連行動について分析を行った. そ の結果, 高群 $(M=5.33)$ は低群 $(M=3.28)$ に比べて実際に, よく遊ん でいた $(F(1,25)=20.82, p \times .001)$ こが示された. このように, 潜在 態度では遊び行動が予測できた. ところが, 顕在態度の指標からは この行動が予測できなかった $(F<1, \mathrm{~ns}$.$) . また, 遊び AMP と顕在態$ 度は相関しなかった( $(\mathrm{r} .12, \mathrm{~ns})$.

勉強 AMP 一方で, 「勉強」への強い潜在態度は, 勉強志向の自己 報告と相関があった $(\mathrm{r}=.48, \mathrm{p}<.05)$ ．ただし，休み中の勉強行動は 潜在態度でも顕在態度でも予測しなかった.

\section{研究 2}

\section{1. 目的}

テスト期間中に AMP の測定を行うことで, テストへの動機づけ が AMPに及ぼす影響を検討する。

\section{2. 方法}

参加者 大学生 36 名 (男性 20 名, 女性 16名).

手続き テスト期間中に，遊びと勉強への AMP を測定した.

\section{3. 結果と考察}

AMP の全体傾向 勉強プライムにおけるポジティブ反応率 (57\%) は，遊びプライム(48\%)や中性プライム $(47 \%)$ に比べて有意に高かっ た $(F(2,70)=5.13, p \times .01)$.これは, テス卜期間でない時期に測定し た研究 1 とは異なる結果である. 寸なわち, テスト期間中では, 勉 強をポジティブに捉えていることが示唆された.

(OIKAWA Masanori, AOBAYASHI Tadashi, KIMURA Haruka) 